\title{
Fiscal Instability in State and Local Public Finance
}

\author{
Freפ C. White and Wesley N. Musser*
}

The problem of fiscal instability in state and local public finance has re-emerged as a result of the frequent recessions experienced during the past decade. Many state and local governments were unprepared for the depth and duration of these recessions and were forced to adjust tax rates, as well as expenditure patterns [1, pp. 57-58]. The public finance literature has considerable material related to the problem of tax instability [2, 5, 11 and 14]. However, the focus of this literature on the narrow issue of tax instability as related to the business cycle has definite limitations in analysis of recent problems of fiscal instability. As Rafuse recognizes [6, pp. 65-66], instability of both revenues and expenditures can contribute to overall budgetary instability. Conceptually, expenditure cash flows could be cyclical and therefore counter tax instability. Intergovernmental transfers and/or debt could provide countercyclical cash flows. Alternatively, countercyclical expenditure patterns and cyclical aid from higher level governments could contribute to budgetary instability.

The purpose of this article is to present a model of fiscal instability which considers the cyclical behavior of all major budgetary categories in state and local government finance. Earlier models of tax instability which consider both secular changes and short-run fluctuations are extended to include instability of all revenues and expenditures. The model developed in this paper is applied to an analysis of budgetary instability problems for the State of Georgia. This empirical application includes a simulation of a recent state fiscal crisis and a consideration of reduction in budgetary instability.

\section{CONCEPTUAL MODEL OF FISCAL INSTABILITY IN STATE AND LOCAL BUDGETS}

In this paper fiscal instability is viewed as fluctuation in budgetary cash flows in response to the business cycle. Fiscal problems from this viewpoint are characterized as cash surpluses during economic expansions and cash deficits during recessions. Such cyclical behavior is anticipated in some state public programs and therefore does not characterize a problem. For example, unemployment insurance programs accumulate reserves during high employment to accommodate

*Professor and Associate Professor, respectively, Agricultural Economics Department, University of Georgia, Athens, Georgia 30602. 
the increase in benefits during a recession when insurance revenues decrease. However, the problems in recent recessions indicated that such anticipated deficits are the exception and that overall cyclical net cash flows is a meaningful analytical viewpoint of a state fiscal problem.

An empirical framework for consideration of fiscal instability can be derived from a definition of budgetary cash flows:

(1) $S=\sum_{i=1}^{m} R_{i}-\sum_{j=1}^{n} E_{j}$

where $\mathrm{S}$ is surplus from budgeted program authorizations,

$R_{i}$ is revenue from source $i$, and

$E_{j}$ is expenditures for program $j$.

In this formulation intergovernmental grants are included as one of the separate revenue sources. Since debt is limited in state public finance by lack of money creation authority and, in many cases, statutory limitations, cash flows from debt are not considered as a revenue or expenditure in the model. Changes in debt are considered part of $\mathrm{S}$ and considered external to the budgetary process in the model.

A measure of the instability of a particular budgetary system can be obtained by differentiating equation (1) with respect to personal income $(\mathrm{Y})$ and converting the result to elasticity measures:

(2) $d S=\left[\sum_{i=1}^{m} a_{i} R_{i}-\sum_{j=1}^{n} b_{j} E_{j}\right] \frac{d Y}{Y}$

where $a_{i}$ and $b_{j}$ are income elasticities.

In this formulation, a positive value for $\mathrm{dS}$ indicates a problem of fiscal instability. If the weighted sum of revenue elasticities has the expected positive sign, fiscal instability can exist under two situations: (1) expenditures are countercyclical which is indicated by the weighted sum of expenditure elasticities being negative, or (2) expenditures are cyclical but the weighted sum of expenditure elasticities is smaller than that of taxes. A priori, either of these situations is plausible. The demand for certain public expenditures would clearly be expected to be related to the business cycle. For example, a slowdown in economic activity would be expected to decrease demands for public recreation. In addition, some flexibility exists in the budgetary political process; for example, the level of salary increases for public employees can be varied with economic conditions. However, expenditures of public welfare would be expected to be countercyclical. Depending on the 
relative share of welfare expenditures in the budget as determined by the magnitude of the $E_{j}$ 's and the level $b_{j}$ for other expenditures, the weighted sum of expenditure elasticities could be negative or positive, but not sufficiently positive to balance the positive weighted revenue elasticities.

While equation (2) is useful for deducing the interaction between revenue and expenditure on overall budgetary instability, it does have limitations in reference to the tax instability literature. Analysis with equation (2) would be based on the budget shares of one period and would fail to trace consequences of secular structural changes in revenues and expenditures on budgetary instability which are independent of short run cyclical fluctuations. Williams, Anderson, Froehle, and Lamb [14, pp 62-68] have noted that a number of other factors can have an effect on tax yields independent of fluctuations in personal income which can also be generalized to expenditures. If it is assumed that these other factors are behaving in a regular secular trend, time can be considered a proxy variable, and each revenue source considered a function of both $\mathrm{Y}$ and time (T).

A formulation of fiscal instability which considers both $\mathrm{Y}$ and $\mathrm{T}$ can be derived by taking the total derivative of (1):

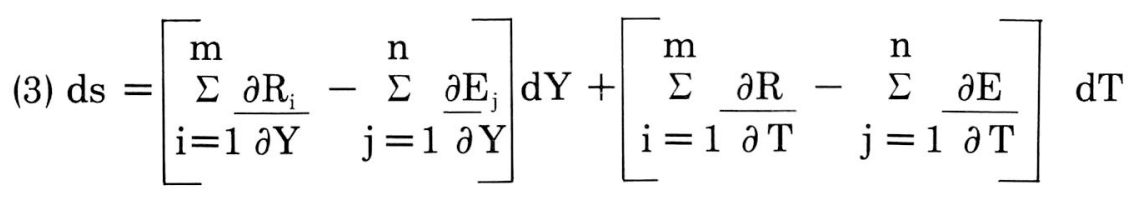

By the use of income elasticities, equation (3) can be rewritten as:

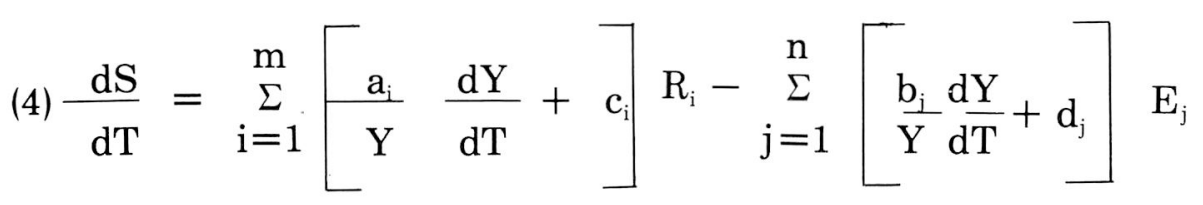

where $c_{i}$ and $d_{j}$ are annual percentage changes in revenues and expenditures, respectively. For a particular budgetary planning period, equation (4) can be approximated in a difference equation:

(5) $\Delta \mathrm{S}_{\mathrm{t}}=\underset{\mathrm{i}=1}{\mathrm{~m}}\left[\mathrm{a}_{\mathrm{i}} \frac{\Delta \mathrm{Y}_{\mathrm{t}}}{\mathrm{Y}_{\mathrm{t}-1}}+\mathrm{c}_{\mathrm{i}}\right] \mathrm{R}_{\mathrm{i}_{\mathrm{t}-1}}-\underset{\mathrm{j}=1}{\Sigma}\left[\mathrm{b}_{\mathrm{j}} \frac{\Delta \mathrm{Y}_{\mathrm{t}}}{\mathrm{Y}_{\mathrm{t}-1}}+\mathrm{d}_{\mathrm{j}}\right] \mathrm{E}_{\mathrm{j}_{\mathrm{t}-1}}$

where $\Delta \mathrm{S}_{\mathrm{t}}=\mathrm{S}_{\mathrm{t}}-\mathrm{S}_{\mathrm{t}-1}$ $\Delta \mathrm{Y}_{\mathrm{t}}=\mathrm{Y}_{\mathrm{t}}-\mathrm{Y}_{\mathrm{t}-1}$. 
Equation (2) and equation (5) are used as the basis for the empirical analysis in this paper. Given elasticity coefficients, $a_{i}$ and $b_{j}$, secular growth trends, $c_{i}$ and $d_{j}$, and absolute budgetary levels, $R_{i}$ and $E_{j}$, this equation can be used to estimate changes in existing surpluses or deficits, $S_{t}$, for a projected change in personal income, $Y_{t}$. Alternatively, the level of $Y_{t}$ can be estimated to eliminate an existing level of $S$. More importantly, the impact of various budgetary reforms on fiscal problems can be estimated. For example, substitution of a sales tax for an income tax would change the level of various $R_{i}$ 's, and thereby change $\Delta \mathrm{S}_{\mathrm{t}}$. As another example, welfare reform could alter the secular increase in expenditures $\left(\mathrm{d}_{\mathrm{j}}\right)$, the elasticity coefficient of welfare expenditures $\left(b_{j}\right)$, or the level of welfare expenditures $\left(E_{j}\right)$, any of which could change $\Delta \mathrm{S}_{\mathrm{t}}$. Some of the possibilities of the equation are illustrated later in the paper. To implement the model, empirical estimates of the parameters are necessary. The next section presents estimates of these parameters for the State of Georgia.

\section{ESTIMATES OF THE PARAMETERS OF THE MODEL}

\section{Methods and Data}

The parameters of the equations developed in the previous section were estimated with the methods developed by Williams, Anderson, Froehle, and Lamb [14] for consideration of tax instability. Their methods involved regressing annual percentage change in each budgetary component $(\mathrm{X})$ on personal income:

$$
\text { (6) } \frac{\Delta X}{X}=e+f \frac{\Delta Y}{Y}
$$

The constant term in the regression equation e represents the annual percentage change in the budgetary variable with no change in income which can be interpreted as secular change in variable $c_{i}$ or $d_{j}$. The slope coefficient $f$ may be defined as the short-run coefficient of income elasticity $\left(a_{i}\right.$ or $\left.b_{j}\right)$. Sign of the coefficient tells whether the budgetary variable is cyclical or countercyclical and size of the coefficient tells the percentage change in the financial variable associated with a one percent change in income which is important in calculating the weighted sums in equation (2) and (5).

Historical data on government budgetary variables used in the analysis were obtained from U.S. Bureau of the Census publications, Governmental Finances [8] and Census of Governments [7]. Personal income for the state was obtained from Survey of Current Business [9]. Budgetary data for selected years are presented in Tables I and II. Wilford [12] suggests that the coefficients estimated with Equation (6) can be unstable if factors affecting cash flows besides income are not subsumed in a regular secular pattern. The financial data were therefore adjusted for such factors as tax rate changes before the regression analysis to preclude this possibility. 
TABLE I. REVENUE SOURCES FOR STATE GOVERNMENT, GEORGIA 1950-1979

\begin{tabular}{|c|c|c|c|c|c|c|c|}
\hline \multirow[b]{3}{*}{$\begin{array}{l}\text { General Sales or } \\
\text { Gross Receipts }\end{array}$} & 1950 & 1955 & 1960 & 1965 & 1970 & 1975 & 1979 \\
\hline & \multicolumn{7}{|c|}{ (Percent) } \\
\hline & 0.0 & 31.0 & 25.9 & 25.0 & 22.3 & 20.9 & 22.2 \\
\hline Motor Fuels & 23.6 & 17.5 & 14.9 & 12.8 & 10.3 & 8.4 & 6.4 \\
\hline Alcohol & 8.4 & 3.3 & 3.6 & 3.9 & 3.8 & 2.8 & 2.2 \\
\hline Tobacco & 6.4 & 2.8 & 3.5 & 4.3 & 2.7 & 2.6 & 1.9 \\
\hline \multicolumn{8}{|l|}{ Motor Vehicle and } \\
\hline Operating License & 2.5 & 2.3 & 3.2 & 3.0 & 2.5 & 1.4 & 1.2 \\
\hline Indivic & 5.4 & 4.4 & 6.5 & 7.7 & 12.3 & 13.8 & 17.6 \\
\hline \multicolumn{8}{|l|}{ Corporation Net } \\
\hline Income & 7.4 & 3.5 & 4.3 & 5.8 & 5.7 & 4.4 & 5.5 \\
\hline Feder & 28.1 & 23.3 & 27.2 & 25.6 & 27.2 & 35.7 & 32.8 \\
\hline All O & 18.2 & 11.9 & 11.0 & 12.0 & 13.3 & 10.0 & 10.2 \\
\hline Total Revenue & 100.0 & 100.0 & $\begin{array}{l}100.0 \\
\text { (Millic }\end{array}$ & 100.0 & $\begin{array}{l}100.0 \\
\text { ars) }\end{array}$ & 100.0 & 100.0 \\
\hline Total Revenue & 203 & 345 & 564 & 832 & 1504 & 2698 & 4144 \\
\hline
\end{tabular}

Source: Annual Reports of the State Auditor of Georgia, Atlanta.

TABLE II. EXPENDITURES FOR STATE GOVERNMENT, GEORGIA 1950-1979

\begin{tabular}{|c|c|c|c|c|c|c|c|}
\hline & 1950 & 1955 & 1960 & 1965 & 1970 & 1975 & 1979 \\
\hline & \multicolumn{7}{|c|}{ (Percent) } \\
\hline Education & 44.1 & 42.8 & 38.2 & 44.0 & 47.7 & 37.6 & 38.8 \\
\hline Highways & 24.4 & 21.1 & 24.8 & 21.7 & 14.2 & 19.7 & 14.9 \\
\hline Public Welfare & 11.0 & 17.0 & 17.4 & 14.4 & 16.3 & 21.2 & 21.1 \\
\hline Health and & & & & & & & \\
\hline Hospitals & 11.0 & 7.8 & 7.4 & 7.0 & 6.9 & 11.1 & 8.6 \\
\hline Natural Resources & 3.1 & 3.2 & 4.2 & 3.7 & 3.5 & 2.6 & 2.4 \\
\hline All Other & 6.4 & 8.1 & 8.1 & 9.2 & 11.4 & 7.8 & 14.2 \\
\hline $\begin{array}{l}\text { Total Expen- } \\
\text { ditures }\end{array}$ & 100.0 & 100.0 & $\begin{array}{c}100.0 \\
\text { (Milli }\end{array}$ & $\begin{array}{l}100.0 \\
\text { n Doll }\end{array}$ & $\begin{array}{l}100.0 \\
\text { ars) }\end{array}$ & 100.0 & 100.0 \\
\hline Total Expenditures & 127 & 395 & 530 & 787 & 1523 & 2698 & 4144 \\
\hline
\end{tabular}




\begin{tabular}{|c|c|c|c|}
\hline \multirow{2}{*}{$\begin{array}{l}\text { Financial } \\
\text { Variables }\end{array}$} & \multirow{2}{*}{$\begin{array}{c}\text { Regression } \\
\text { Constant }\end{array}$} & \multicolumn{2}{|c|}{ Short-run Income elasticity } \\
\hline & & Coefficient & Student-t \\
\hline \multicolumn{4}{|l|}{ Tax Revenues } \\
\hline Individual income & 0.4228 & 1.5659 & 2.19 \\
\hline Corporate income & 0.0647 & 0.8042 & 1.15 \\
\hline Sales & 2.0183 & 0.7916 & 3.8513 \\
\hline Alcoholic beverage & -1.5675 & 1.2163 & 2.811 \\
\hline Tobacco & 5.7081 & 0.1347 & 0.21 \\
\hline Motor fuel & 3.7529 & 0.4491 & 1.34 \\
\hline $\begin{array}{l}\text { Motor vehicle and } \\
\text { operators license }\end{array}$ & & & \\
\hline operators license & 11.1904 & -0.0310 & -0.0256 \\
\hline Federal Aid & 3.6352 & 0.9060 & 1.8606 \\
\hline \multicolumn{4}{|l|}{ Expenditures } \\
\hline Education & -2.4434 & 0.7290 & 1.7466 \\
\hline Highways & 7.8837 & 0.1198 & 0.1311 \\
\hline Public welfare & 8.0373 & -0.4434 & -1.2516 \\
\hline Health and hospitals & 7.1846 & 0.3433 & 0.5304 \\
\hline Natural resources & 7.0168 & 0.4422 & 0.4624 \\
\hline
\end{tabular}

\section{Empirical Estimates}

The results of the regression analysis for budgetary categories for the State of Georgia are presented in Table III. These estimates were based on time series data for the period 1952 through 1973. In general, the estimates appear reasonable and consistent with previous research. The short-run income elasticity of individual income taxes, corporate income taxes, and sales taxes are $1.56,0.80$, and 0.79 , respectively, which are generally higher than the other special excise taxes. The positive income elasticity on all taxes, except motor vehicle and operator license, confirms that tax revenues are cyclical. The income elasticity for federal aid is 0.9060 which indicates that grants are also cyclical and contribute to fiscal instability. The results for federal grants are consistent with earlier research [6, p. 70].

The results for expenditures indicate that all categories except public welfare are cyclical. However, none of the income elasticity coefficients are significantly different from zero and the positive coefficients are all in the inelastic range. These results indicate that state expenditures cannot be freely adjusted in the legislative appropriations process to changing short-run economic conditions. This conclusion is consistent with the general literature on public expenditures. Wildavsky [13] has argued that the annual appropriations procedure is incremental with expenditures in various categories being increased by historically constant proportions. Relative levels of increases vary with the historical political support for various components. A particular budgetary facet which supports this incremental process is that many public expenditures are uncontrollable or exogenous to annual 
appropriation decisions. Weidenbaum [10] identified four major institutional forms of program appropriations which are relatively uncontrollable-trust funds, permanent and indefinite appropriations, fixed charges, and ongoing projects and estimated that a majority of the total federal budget was in these categories.

\section{BUDGET INSTABILITY FOR THE STATE OF GEORGIA}

In this section, the budgetary parameters estimated in the previous section are utilized to analyze some problems of fiscal instability for the State of Georgia within the theoretical framework developed earlier in the paper. The evolution of fiscal instability problems in Georgia is considered as a prelude to simulation of the fiscal crisis during the 1975 recession. Finally, the impact of some program reforms on budgetary instability are considered.

\section{Evolution of Fiscal Instability}

The static measure of fiscal instability represented by equation (2) is presented in Table IV for the State of Georgia for selected years. These measures used the estimated previously presented (Tables I, II and III). Revenue instability, which is in the first column of Table IV, is the value of the first term in equation (2), the weighted sum of the revenue elasticities with the weight being the amount of revenue. Expenditure instability represents the second term of equation (2) which is the weighted sum of the expenditure elasticities. Finally, budget instability represents $\mathrm{dS}$ which is the difference between the first two columns. Each of these measures can be interpreted as the absolute change in the magnitude of the budgetary component resulting from a one percent change in personal income.

Budgetary instability increased from 1950 to 1975 for all three categories. Aggregate revenue instability was $\$ 1.3$ million in 1950 and had increased 18.8 times to $\$ 24.2$ million by 1975 even though total revenues increased only 15.2 times. Aggregate expenditure instability was $\$ 0.5$ million in 1950 , which may account for the fact that it was virtually ignored in earlier analyses. By 1975 expenditure instability was $\$ 7.4$ million. Budgetary instability was $\$ 0.8$ million in 1950 and was $\$ 17.1$ million in 1975 , which was 21.4 times larger than in 1950 . The magnitude and absolute increases in revenue instability were greater throughout the period which indicates the focus of the literature on tax instability.

The changes in structure of the aggregate budgetary categories which produced the changes in fiscal instability can be identified in Tables I and II. Between 1950 and 1975, individual income taxes increased from 6.2 percent to 13.8 percent, general sales taxes increased from 0 percent to 20.9 percent, and federal aid increased from 28.2 percent to 35.7 percent. These sources have larger income elasticities (Table III) than the revenue sources they relatively displaced. At the same time, the structure of expenditures remained relatively constant so 
TABLE IV. FISCAL INSTABILITY IN THE GEORGIA STATE BUDGET, 1950-1975

\begin{tabular}{lccc}
\hline Year & $\begin{array}{c}\text { Revenue } \\
\text { Instability }\end{array}$ & $\begin{array}{c}\text { Expenditure } \\
\text { Instability }\end{array}$ & $\begin{array}{c}\text { Budgetary } \\
\text { Instability }^{\mathrm{b}}\end{array}$ \\
\cline { 2 - 4 } 1950 & 1.3 & (Million Dollars) & \\
1955 & 2.6 & 0.5 & 0.8 \\
1960 & 4.4 & 1.3 & 1.3 \\
1965 & 6.7 & 1.6 & 2.9 \\
1970 & 14.2 & 2.8 & 3.9 \\
1975 & 24.4 & 5.9 & 8.3 \\
\hline
\end{tabular}

${ }^{a}$ Fiscal instability reflects the impact of a one percent increase in personal income on the State's revenues and expenditures.

${ }^{b}$ Budgetary instability is the difference between revenue and expenditure instability.

that expenditure instability did not keep pace with revenue instability. Thus, the substitution of the more elastic revenue sources was the main source of growth in budget instability.

Simulation of Impact of Fiscal Instability

For simulation of the fiscal situation in a particular budgetary period, equation (5) is necessary to account for the secular structural changes in revenues and expenditures. In this section, the data in Tables I, II, and III are used in this dynamic equation to simulate the fiscal crisis in Georgia in 1975-76. For this simulation, equation (5) is added to $S_{t-1}$ to produce a relationship for current surplus:

$$
\text { (7) } \left.\mathrm{S}_{\mathrm{t}}=\mathrm{S}_{\mathrm{t}-1}+\Delta \mathrm{S}_{\mathrm{t}}=\frac{\mathrm{f}\left(\Delta \mathrm{Y}_{\mathrm{t}}\right.}{\mathrm{Y}_{\mathrm{t}-1}} \mid \mathrm{S}_{\mathrm{t}-1}\right)
$$

This equation is graphed in Figure I.

The fiscal crisis in 1975-76 can be explained with reference to this Figure. Given the structure of revenues and expenditures, the State would have had to experience almost a two percent increase in income to have a zero surplus. This necessary increase in income resulted from secular increases in expenditures such as built-in step raises for employees and inflation. During the 1975 legislative session, the General Assembly developed the budget for fiscal year 1976 with the assumption that the State would continue to experience some economic expansion. The economic situation subsequently worsened with personal income actually declining for a few months. The General Assembly rescinded pay raises in excess of $\$ 50$ million to state employees and school teachers in a special session called to deal with the fiscal crisis. At a later date the Governor cut the budget an additional $\$ 50$ million through administrative decree. Referring to Figure I, 
expectations of growth in personal income of 5 percent at the time the budget was developed would have yielded a surplus of $\$ 50$ million and thus provide enough additional revenue for the raises. However, by the time the budget was actually implemented an expectation of a 2 percent decrease in personal income would have resulted in a deficit of $\$ 100$ million in the new budget. Thus, the fiscal instability model for Georgia developed in this paper is consistent with actual budgetary conditions which indicates that the economic framework developed in this paper is useful for the budgetary planning process.

\section{Budgetary Reform}

For periods in which the economy is expected to fluctuate widely, the state government might desire to have less fiscal instability. By reducing its fiscal instability as measured by equation (2) to zero, its budget would be balanced regardless of the level of economic activity. In reference to equation (2), fiscal instability can be reduced by lowering the income elasticity of revenues, raising the income elasticity of expenditures, and/or increasing the relative component of budgetary components with the appropriate elasticities. While analysis of the first two reforms is beyond the scope of this paper, examples of the latter can be derived from data developed in this paper.

One example is the replacement of the more volatile individual income tax with the more stable sales tax. In 1975, the individual income tax yielded 373.23 million dollars (Table I) and had an income elasticity of 1.569 (Table III). The contribution of the income tax to fiscal instability for a one percent change in personal income can be determined by multiplying 373.23 by 1.569 and .01 which equals 5.8 million dollars. Since sales tax had an elasticity of .7916 (Table III), an increase in sales tax sufficient to yeild 373.23 million more dollars in 1975 would result in an increase in fiscal instability of 2.9 million dollars. The net decrease in fiscal instability would then be 2.9 million dollars (5.8-2.9).

An additional example involves federalization of public welfare expenditures. Similar calculations result in -2.5 million dollars. Since the expenditure term in equation (2) is subtracted from the revenue term, the impact of zero public welfare expenditures would be a reduction of 2.5 million dollars. The total impact of fiscal instability must also take into account the budgetary structural changes stemming from replacement of former public welfare expenditures. If the funds were used to increase education expenditures, fiscal instability would decrease 4.17 million dollars more for a total effect of 6.67 million dollars. Alternatively, use of the funds to reduce sales taxes would result in a further decrease of 4.5 million dollars for a total of 7.0 million dollars reduction for a one percent change in personal income. Other budgetary reforms could be analyzed in a similar manner.

\section{IMPLICATIONS}

This paper has developed a framework to quantify fiscal instability in the state and local governmental process which extends earlier 
research methods in tax instability to include all major revenue and expenditure components. The application of this framework to the state government of Georgia demonstrated the usefulness of the framework in analysis of fiscal instability. Empirical analysis for Georgia quantified the emergence of the fiscal instability problem, simulated the fiscal crisis during the 1975-76 recession, and indicated some budgetary reforms which would reduce fiscal instability. This analysis indicated that more research within this framework is warranted. In particular, existing methodology on estimation of income elasticities needs more development in order to develop estimates with better statistical properties than those used in this paper. In addition, methods to analyze the impact of program reforms on income elasticity warrants consideration.

Despite the weaknesses in methodology, this paper does have some important policy implications. Recent fiscal crises evidenced in state and local public finance indicate that analysis of public programs needs to be broadened from its current efficiency emphasis, as characterized by Program Planning and Budgeting, to include a stabilization emphasis. In emphasizing stabilization, it must be recognized that countercyclical public finance is the domain of the federal government rather than state and local governments. Expenditures which are insensitive to business cycles or are countercyclical therefore are more properly financed by the federal government. This principle gives strong support to the federalization of all welfare programs. Federal support should emphasize expenditures which are the most difficult to contract or expand in response to business cycles. These policy prescriptions, in part, do conflict with prescriptions based on equity and/or efficiency.

The present system of intergovernmental transfers, which has been designed with efficiency and equity in mind, contributes to economic instability rather than moderating the impact of business cycles. As long as intergovernmental transfers are directly linked to the granting government's revenue, these grants will be subject to economic fluctuations. However, intergovernmental transfers could be used to stabilize the flow of funds to state and local governments. While the federal government could use tax credits to stimulate economic activity and indirectly raise state and local government revenue, only grants-in-aid would directly ensure that the desired impact on state and local governments would be achieved.

While the above policy prescriptions to dampen fiscal instability have been directed primarily at the federal level, state and local governments can also act to stabilize cash flows. As state and local revenue sources are introduced and/or expanded, their impact on stability should be taken into consideration. The optimal tax structure should be based on equity, efficiency, economic growth and stability. State and local governments should also take flexibility and controllability into consideration when expanding expenditure programs. Some programs can be designed to provide more flexibility without seriously affecting service levels. For example, capital expenditures in some areas could be coordinated with available revenues. Other cash 
flows such as stabilization reserves and debt could be designed to provide added flexibility. In particular, a close examination of the effects of existing debt limits on fiscal instability is warranted.

Further extensions of the research reported in this paper appear warranted. The revenue and expenditure components were viewed as being independent. However, sales taxes are allowed as part of business costs or are deductible from taxable personal income (or income taxes). Also, some federal grants require matching funds from state and local governments. Hence, the interaction among revenue and/or expenditure components could be taken into consideration.

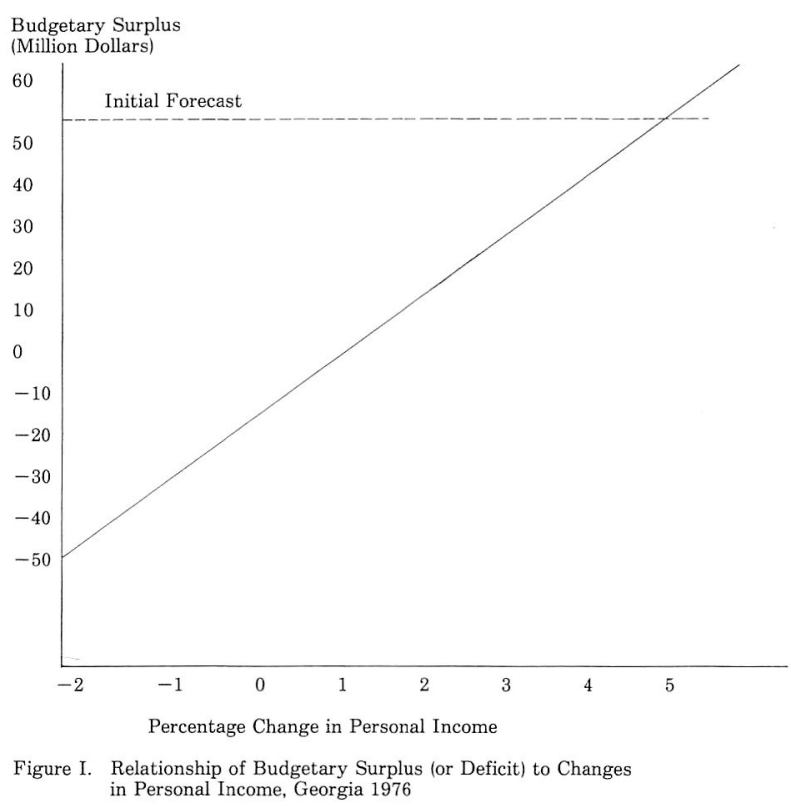

REFERENCES

1. Council of Economic Advisers. Economic Report of the President. Transmitted to Congress January 1976. Washington, D.C.: U.S. Government Printing Office, 1976.

2. Groves, Harold M. and C. Harry Kahn. "The Stability of State and Local Tax Yields." American Economic Review, March 1952, 87-102.

3. Hansen, Alvin H. and Harvey S. Perloff. State and Local Finance in the National Economy. New York: W. W Horton and Company, Inc., 1944.

4. Hirsch, Werner Z. The Economics of State and Local Government. New York: McGraw-Hill Book Company, 1970.

5. Musgrave, Richard A. The Theory of Public Finance. New York: McGraw-Hill Book Company, 1959.

6. Rafuse, Robert W., Jr. "Cyclical Behavior of State-Local Finances." Essays of Fiscal Federalism. ed. Richard A. Musgrave, Washington, D.C.: The Brookings Institution, 1965, 63-121.

7. U.S. Bureau of the Census. "Historical Statistics on Governmental Finances and Employment." Census of Governments, 1972. Washington, D.C.: U.S. Government Printing Office, April 1975 and previous issues.

8. U.S. Bureau of the Census. Governmental Finances in 1972-73. Washington, D.C.: U.S. Government Printing Office, 1975 .
9. U.S. Bureau of Economic Analysis. Survey of Current Business. Washington, D.C.: U.S. Government Printing Office, April 1975 and previous issues.

10. Weidenbaum, Murray L. 'Budget 'Uncontrollability' as an Obstacle to Improving the Allocation of Government Resources." The Analysis and Evaluation of Public Ex penditures: The PPB System. A Compendium of Papers Submitted on Economy in Government of the Joint Economic Committee, Congress of the United States, 91st Congress, 1st Session, Vol. 1, Washington, D.C.: U.S. Government Printing Office, 1969.

11. Wilford, Walton T. "State Tax Stability Criteria and the Revenue-Income Elasticity Coefficient Reconsidered. " $\mathrm{Na}$ tional Tax Journal, September 1965, 304-312.

12. Wilford, Walton T. A Comment on "The Stability, Growth, and Stabilizing Influence of State Taxes." $\mathrm{Na}$ tional Tax Journah December 1975, 452-458.

13. Wildavsky, Aaron. The Politics of the Budgetary Process. Boston: Little, Brown and Company, 1964.

14. Williams, William V., Robert M. Anderson, David O. Froehle and Kay L. Lamb. "The Stability, Growth and Stabilizing Influence of State Taxes." National Tax Journal, June 1973, 267-273. 